\title{
Threats to Gelada Baboons (Theropithecus Gelada) in and Around Jer Silase Monastry in Amhara National Regional State, North Shoa Zone, Ethiopia
}

\author{
Tamenut Desalegn \\ Mekdela Amba University College of Agriculture and Natural Resource
}

\begin{abstract}
The study was carried out in and around Jer Silase Monastry in Amhara National regional State, North Shoa Zone, from July 2019 to February 2020. The study aimed to determine threats of gelada baboons. The data was collected through questionnaires, household survey, direct observation and focus group discussions. Sample size was determined with Israel's formula (1992). Statistical Package for Social Sciences (SPSS) version 20 Computer software program, using descriptive statics and chi-square test to compare responses of respondents. The attitudes of literate respondents and illiterate respondents towards gelada baboons were highly significant difference $\left(\chi^{2}\right.$ $=50.84, \mathrm{df}=1, \mathrm{p}=0.00<0.05)$. Habitat lose and destruction $(92.7 \%)$ expansion of agriculture $(89.7 \%)$, Charcoal production $(83.2 \%)$, fire $(73.9 \%)$, lack of awareness $(72.3 \%)$, administrative problem $(69.9 \%)$ and human gelada conflict $(69.6 \%)$ were major threats of gelada baboons identified in the study area. Those threats were directly or indirectly affecting the habits, growths and lifespan of gelada baboons. Government officials, NGOs and local community participation are needed for conservation of gelada baboons.
\end{abstract}

Keywords: Gelada baboons, Jer Silase Monastry, Threats

DOI: $10.7176 / \mathrm{JNSR} / 11-19-03$

Publication date:October $31^{\text {st }} 2020$

\section{Introduction}

Ethiopia is one of the top 25 biodiversity rich countries in the world and hosts two of the African biodiversity hotspots, namely the eastern Afromontane and the horn of Africa hotspots (Conservation International, 2011). But, wildlife resources of Ethiopia are fall under pressure from different direct or indirect causes of human activities (Wilfred, 2010). The threats include livestock encroachment, poaching for subsistence purpose, habitat degradation due to deforestation, encroachment of incompatible land uses and uncontrolled fire, invasive species, lack of awareness and administrative problem (Afework Bekele, 1996; Donald and Evans, 2006; Sara et al., 2014). Deforestation and forest degradation are occurring globally at an alarming rate that results in decline of the total area of primary forests (Bethan, 2012). Loss of habitat is the main threat to biodiversity and is the major contributor to global species extinction (Fahrig, 2001). The increment of economic productivity, humans alters the landscape matrix in ways that affect the spatial density, diversity and quality of wildlife habitat (Radeloff et al., 2005).

The rapid and unplanned expansion of urban and agricultural areas is a common pattern in developing countries (Girma Mengesha et al., 2014). Consequently, human being affects wildlife through habitat degradation and destruction. Many forest resources of Ethiopia diminished due high human encroachment for agriculture, pastureland, collection of firewood, timber production, charcoal production, livestock encroachment and settlement. Hence, these factors directly or indirectly affect the habitats of wildlife. As a result, wildlife of the country is now largely restricted within a few protected areas. However, those protected areas are exposed to severe pressure risking the mammals living inside to the level threatens their existence and sustainability due to anthropogenic effects (Alemneh Amare, 2015). This leads to affect wildlife's including gelada baboons.

Therefore, this study emphasis on threats to gelada baboons in and around Jer Silase Monastry, in Amhara National regional State, North Shoa Zone and gather information about how much local community disturb gelada baboons. Also fill the knowledge gap on gelada baboons, suggest solutions for conservation problems, and give applicable information about the challenges to gelada baboon conservation for local and regional administration. Eventually, the study also combined interview using questionnaire to evaluate various parameters.

\section{Materials and Methods}

Study area Description

The study was carried out in and around Jer Silase Monastry in Amhara National regional State, North Shoa Zone, Lemi (Ensaro) woreda shown as (figure 1). The area is located $135 \mathrm{~km}$ in North part of Addis Ababa, the capital city of Ethiopia. It is located between $9^{\circ} 44^{\prime} 80^{\prime \prime} \mathrm{N}$ latitude and 38 $57^{\prime} 07^{\prime \prime} \mathrm{E}$ longitude in the Amhara Regional state, Ethiopia, between an altitudinal range of 2100-2551 m a.s.l. 


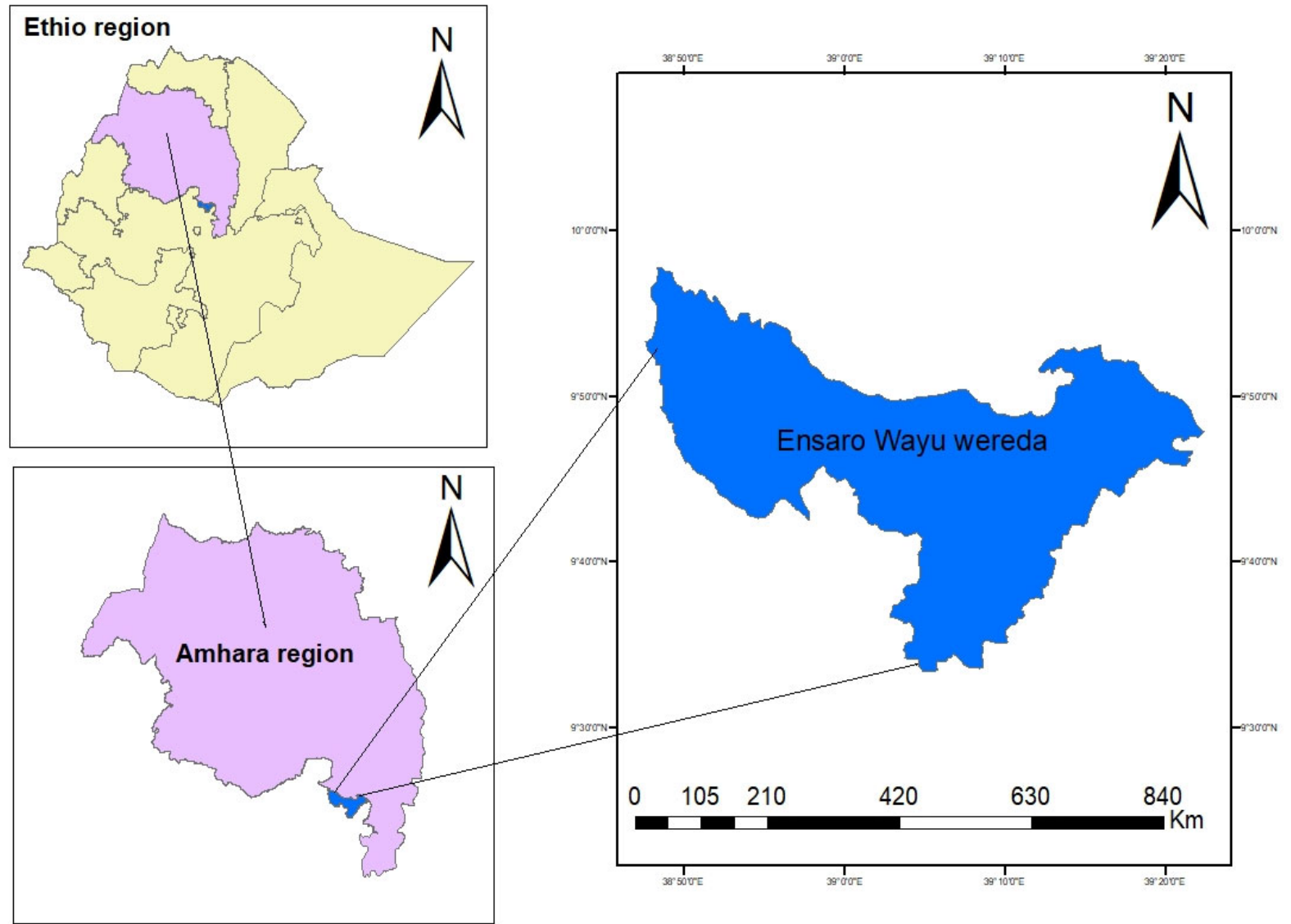

Figure 1 Map of the study area

The study area has unimodal patterns of rainfall. The rain mainly falls from with four months (June to September), with the highest concentration in July and August. The annual precipitation ranges from $800 \mathrm{~mm}$ to $1200 \mathrm{~mm}$. The mean monthly maximum and minimum temperature of the study area is $23.5^{\circ} \mathrm{C}$ and $16^{\circ} \mathrm{C}$ respectively. The hottest month is March with maximum temperature of $26.13{ }^{\circ} \mathrm{C}$ and the coldest month is December with a temperature record of $15.5^{\circ} \mathrm{C}$.

\section{Data collection and Sampling design}

A preliminary survey was carried out in June, 2019 to gather basic information about the study site. During this period collect information about physical features, demographic and threats to Gelada baboon in the study site were assessed using ground survey. The actual study was carried out from July, 2019 to February, 2020.

To achieve the objectives of the present study, there are different complementary data collection methods namely semi structured questionnaires, household survey, direct observation and focus group discussions were used. The study area enclosed by five districts Antsokia, Jer, Girarge, Wokelo and Kabi kebeles. Sample size determination is important to infer the results for the whole populations. The total sample size was determined using Israel's formula (1992).

$\mathrm{n}=\frac{N}{1+N\left(e^{2}\right)}$

Where, $\mathrm{n}$ is number of respondents drawn from total population; $\mathrm{N}$ is the target population size and $e$ is the level of precision. For selection of informants from each Kebele, a proportional allocation formula was used (Kothari, 2004) and calculated as:

$$
n=\frac{\text { Number of total population in each Kebele } \mathrm{X} \text { Total sample size }}{\text { Total population of the study site }}
$$

From the total population of 65,892 , a total of 398 respondents were selected for questionnaires. That is $\mathrm{n}=$ $65,892 / 1+65,892(0.05)^{2}=398$. The respondents selected randomly from the district kebeles to acquire information regarding socio-demographic data (such as age, sex and educational status) and threats of Gelada baboon 
(Theropithecus gelada) in the various aspects of the study area. Direct observation was another method used to collect primary data and carry out through systematic and purposeful observation. The observation was carried out in the selected sample Kebele of the district during the study period, through recording information about threats were undertaken by using observation checklists. Focus group discussion (FGD) was the third method helps to acquire useful and detailed information from similar background or experiences to discuss on specific issue of interest. This method provides insights into how people think and provide a deeper understanding of the threats and phenomena being studied. Discussions were made with purposively selected 6-12 respondent in each Kebele. The participants were selected purposively based on the responsibilities and experience they have and relevance to issues understudy. In Antsokia kebele the discussion group was made up of 3 experts from Rural Development and Agricultural Extension (RDAE), 4 experts from forestry enterprise of the districts, 2 peoples from kebele administrators and 3 experts from teachers of the district. In Jer kebele 4 elders of the district, 3 students, 2 experts from Rural Development and Agricultural Extension and 2 monastry administrators of the district. Where as in Girarge kebele 1experts from Rural Development and Agricultural Extension, 3 elders of the kebele, 2 experts from wildlife and tourism office and 3 peoples from kebele administrators of the district. In kabi kebele 4 experts from Rural Development and Natural Resource Management office, 2 experts were teachers and 3 local elders. All participants' discus and express their feeling freely related to issues of threats of gelada baboon.

\section{Data analysis}

The data was analyzed by using Statistical Package for Social Sciences (SPSS) version 20 Computer software program using descriptive statics and chi-square test. The statistical test used was two-tailed with $95 \%$ confidence intervals. Descriptive statistic such as, percentages, frequency, tables, figures and graphs were applied to organize, analyze and interpret the results.

\section{Results}

The demographic information of respondents from the society who were provided with a structured questionnaire to assess their views towards threats of gelada baboons in and around Jer Silase Monastry indicated in (Table1). Out of the total respondents, $56.3 \%$ were males and $43.7 \%$ were females. There is no significant difference between the number of male and female respondents $\left(\chi^{2}=1.98, \mathrm{df}=1, \mathrm{p}=0.23>0.05\right)$. Table 1: Description of demographic background of the respondents

\begin{tabular}{llll}
\hline Variable & Category & Frequency & Percentage \\
\hline Sex & Male & 224 & 56.3 \\
& Female & 174 & 43.7 \\
\hline Age & $10-20$ & 58 & 14.6 \\
& $21-30$ & 62 & 15.6 \\
& $31-40$ & 174 & 43.7 \\
& 41 and above & 104 & 26.1 \\
\hline Marital status & Married & 230 & 57.8 \\
& Unmarried & 99 & 24.9 \\
& Divorced & 69 & 17.3 \\
\hline Occupation & Farmer & 231 & 58.0 \\
& Student & 59 & 14.8 \\
& Government worker & 108 & 27.1 \\
\hline Education & Literate & 147 & 36.9 \\
& Illiterate & 251 & 63.1 \\
\hline
\end{tabular}

Out of the total respondents provided in questionnaire $(57.8 \%)$ were married, $(24.9 \%)$ were unmarried and $(17.3 \%)$ were divorced. The majority $(63.1 \%)$ of the respondents were illiterate with reading skills acquired without attend formal education and $(36.9 \%)$ were literate with attend formal education. There is highly significant difference among literate and illiterate respondents $\left(\chi^{2}=50.84, \mathrm{df}=1, \mathrm{p}=0.00<0.05\right)$. Out of the total respondents $(43.7 \%)$ were age ranges from 31-40 years, $(26.1 \%)$ were age ranges 41 and above, $(15.6 \%)$ were age ranges 21 30 years and $(14.6 \%)$ were age ranges $10-20$ years. The bulk of respondents $(58.0 \%)$ were farmers, $(27.1 \%)$ government worker and $(14.8 \%)$ were students. There is significant difference between occupation of the respondents $\left(\chi^{2}=18.98, \mathrm{df}=1, \mathrm{p}=0.001<0.05\right)$.

Depending of the views of respondents habitat lose and destruction $(92.7 \%)$ was the major problems recorded in the study area as shown in (Table 2), followed by expansion of agriculture $(89.7 \%)$, Charcoal production $(83.2 \%)$, Fire $(73.9 \%)$, lack of awareness $(72.3 \%)$, administrative problem $(69.9 \%)$ and human gelada conflict $(69.6 \%)$, respectively. 
Table 2: Respondents result on threats to gelada baboons (Theropithecus gelada)

\begin{tabular}{|c|c|c|c|c|c|c|c|c|c|c|}
\hline \multirow{3}{*}{ Threats of Gelada baboon } & \multicolumn{10}{|c|}{ Levels of agreement } \\
\hline & \multicolumn{2}{|c|}{$\begin{array}{l}\text { Strongly } \\
\text { agree }\end{array}$} & \multicolumn{2}{|c|}{ Agree } & \multicolumn{2}{|c|}{ Neutral } & \multicolumn{2}{|c|}{ Disagree } & \multicolumn{2}{|c|}{$\begin{array}{l}\text { Strongly } \\
\text { disagree }\end{array}$} \\
\hline & $\mathrm{F}$ & $\%$ & $\mathrm{~F}$ & $\%$ & $\mathrm{~F}$ & $\%$ & $\mathrm{~F}$ & $\%$ & $\mathrm{~F}$ & $\%$ \\
\hline Habitat lose and destruction & 117 & 29.4 & 252 & 63.3 & 12 & 3.0 & 17 & 4.3 & 0 & 0 \\
\hline Expansion of agriculture & 97 & 24.4 & 260 & 65.3 & 12 & 3.0 & 26 & 6.5 & 3 & 0.8 \\
\hline Fire & 44 & 11.1 & 250 & 62.8 & 19 & 4.8 & 79 & 19.8 & 6 & 1.5 \\
\hline Lack of awareness & 36 & 9.0 & 252 & 63.3 & 35 & 8.8 & 64 & 16.1 & 11 & 2.8 \\
\hline Administrative problem & 60 & 15.1 & 218 & 54.8 & 24 & 6.0 & 83 & 20.9 & 13 & 3.3 \\
\hline Charcoal production & 99 & 24.9 & 232 & 58.3 & 13 & 3.3 & 50 & 12.6 & 4 & 1.0 \\
\hline Human with gelada conflict & 44 & 11.1 & 233 & 58.5 & 21 & 5.3 & 93 & 23.4 & 7 & 1.8 \\
\hline
\end{tabular}
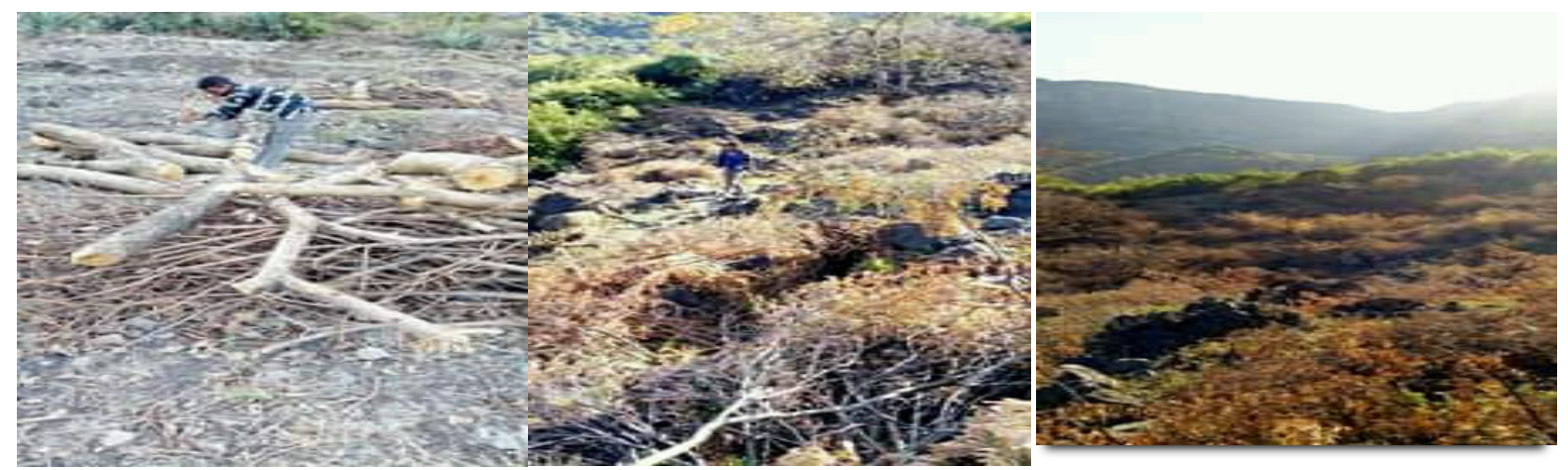

Figure 2 Local communities destruct habitats of gelada baboons for charcoal, fire wood and additional farmland area

\section{Discussion}

Most of the respondents $(86.3 \%)$ that provided in the focused group discussions were knew the threats of gelada baboons and few of respondents $(13.7 \%)$ didn't have information threats of the gelada baboons. Some of respondents $(79.6 \%)$ had negative attitude towards gelada baboons and few of $(20.4 \%)$ had positive attitude towards gelada baboons. In the present study, the local communities who participated for interview were not joyful with the existence of gelada baboons. They considered as gelada baboons were one of the limiting factors to increase agricultural production due to crop raiding problem they cause for local communities. In line with this study, Kassahun Abie and Afework Bekele (2016) found that gelada baboons were a limiting factor to improve the livelihood of the people. In contrary to this study, Melese Yhune et al. (2009) in and around the Simien Mountain National Park and Engdasew Andarge (2010) around Guassa Community Conservation Area.

Land use change due to population increase is quite common in protected areas of most Eastern African countries (Pomeroy et al., 2003). Due to increasing human population, encroachment in to the wildlife area increases and more lands adjacent to the wildlife area used for farmland, this creates pressure on wildlife population (Sefi Mekonen et al., 2017). Conversion to agricultural land use results in a loss of habitat, reduction in patch size and an increase in distance between patches and new habitat formation (Anderson, 1994). In Ethiopia, land is being converted for subsistence and commercial agriculture, livestock encroachment, charcoal production and fire wood collection. As identified by respondents in the study area, wildlife threats were habitat loss, fire, and expansion of agricultural practices, human wildlife conflict, livestock encroachment, charcoal production, lack of awareness, lack of effective management and administration problems.

The major economic activities of local communities who live around Jer Silase Monastry are farming, selling fire wood and charcoal production. Due to this communities directly or indirectly destruct wildlife habitats including gelada baboons. Habitat loses and destruction $(92.7 \%)$ was the major problems to continue living of gelada baboons (Theropithecus gelada) around Jer Silase Monastry (Figure 2). As human population increase the demand of food and extra agricultural land also increase, due to this they destruct the habitats of gelada baboons. Similarly, in this study, Meduna et al. (2009), Kassahun Abie and Afework Bekele (2016) reported that the demand of food and farmland increase, constriction of ranges and led to change on composition and structure of the habitat. $89.7 \%$ of respondents reported explanation of agriculture was the second major threats of gelada baboons. Local peoples produce different cereal crops like wheat, sorghum, teff, barley and bean. To cultivate that cereal crops societies destruct habitats of gelada baboons and chased gelada baboons away from the farmland areas through sling, shouting with gun powder and throwing with stones, they also exhausted high guarding investment, disruption of schooling for children who have to help guard fields. In line this study, Gippoliti and Hunter (2008) 
found that the overall range of the Gelada is being eroded as a result of agricultural expansion due to the increasing human population densities on the central highlands.

Charcoal production (83.2\%) was a major threat to gelada baboons reported as respondents. It was one of the traditional fuel energies in Lemi/Ensaro wereda. In line this study, Solomon Chanie and Dereje Tesfaye (2015) findings charcoal production was an important source of energy in developing countries including Ethiopia and Dawit Diriba (2012) found that charcoal production was the main economic activity in developing countries. Above and beyond of this wildlife population was adversely affected including gelada baboons. Similarly, this study, Sefi Mokonin et al. (2017) suggested that illegal charcoal production was a major cause of deforestation that might be directly influenced wildlife's habitat.

Of the respondents view fire (73.9\%) was one of the most troubles to gelada baboons in the study area. During the month of May and June local communities began prepare their farmland for cultivation of crops due to that they combustion bush, grasses and forests in and near to the farmland. They think fire remove the old fodders and grasses, in place of that during the raining time much amount of new grasses produce. Due to this, it often results in difficult to control automatically bush encroachment, greatly reduced forage production and changes to the structure and composition of the vegetation. Similarly, this study, Kassegn Berhanu and Endalkachew Teshome (2018) who have stated fire as critical factor that devastates wildlife resources and once it is intense. In addition to this, Ethiopian Panel on Climate Change (2015) suggested that light fires uncontrolled and deliberate fire set to gain agricultural land and fresh green fodder it can emerge from uncontrolled use and cause a huge damage on the ecosystem, particularly in the subafroalpine ecosystem.

Many of $(72.3 \%)$ respondents living around Jer Silase Monastry they imagine gelada booboos are inconvenience animal that damage crops. In this study indicated that the majority of local communities were not aware gelada baboons. Majority of the local peoples were illiterate without attend formal education; those communities had negative attitude towards gelada baboons. In contrary, Engedasew Andarge (2010) study around Guassa community conservation area North Shoa Ethiopia. But, a few of communities were literate with attend formal education and had awareness towards gelada baboons. In line with this study, Kwaslema et al. (2018) finding educated peoples had more awareness towards wildlife than an educated people. Mengistu Wale et al. (2017) also suggested that the lack of awareness was the major conservation challenges of wildlife in the eastern part of Ethiopian protected area.

Some $(69.9 \%)$ of respondents were believed that Administrative problem was one of the challenges to gelada baboons in the study area. Local communities and also governmental bodies in Lemi weredas and around Jer Silase Monastry not give attention towards gelada baboons and there are no boundary demarcation habitats of gelada baboons. In line Linnell et al. (2005) Zoning is used essential geographically differentiated land management zones where different forms of places are widely used for designed to manage wildlife and other protected areas. In the study area there is no responsible body take punishment on criminates to gelada baboons.

Human-wildlife conflict is a major load of most people living next to protected areas in developing countries due to their subsistent live (Alemneh Amare, 2015). According to the respondents reported as (69.6\%) of problem was human with gelada conflict. One major cause for human-wildlife conflict is increasing human population adjacent to the protected area (Melese Yihune et al., 2009). As human population increases the demand for farmland increase, due to this local community destruct, disturbed, altered wildlife habitats and competition on foraging in the area including gelada baboons. Hence species that are incapable to acclimate to altered habitats are forced to decrease their number and occupy the peripheral habitats (Melese Yihune et al., 2009). Nevertheless, those species that are able to acclimate an altering ecology and endure in agricultural system become elaborate in a direct struggle with humans (Deresse Dejene, 2003). In addition to this gelada baboon raided cultivated crops and local communities chased gelada baboons away from near the farmland areas. Agreement with Melese Yihune et al. (2009) notices that gelada baboons were the main causes of conflict with local communities since their farmlands in these villages were located near to the habitats of gelada baboons.

\section{Conclusion}

Every living organism in nature fights each other to survive and continue existing in the ecosystem. The cause of struggle is due to limited supply of resources like water, food, habitat, space, farmland and other resources. The demand of local communities increases towards farmland areas time to time and they destruct the habitats of gelada baboons. Due to this gelada baboons raiding cultivated crops and peoples chased gelada baboons away from the farmland areas. This causes struggle between local communities and gelada baboons. Since, the arrogances of local communities towards gelada baboons negative. Generally, in this study gelada baboons were strongly challenged to survive as the condition influenced by local communities.

The main threats of gelada baboons identified in and Jer Silase Monastry were Habitat destruction, agricultural explanation, charcoal production, fire, administrative problem, lack of awareness and human gelada baboon conflict. These threats directly or indirectly affect the habit of gelada baboons in the study area. 


\section{Recommendations}

Even if gelada baboons alive in and around Jer Silase Monastry the area was affected by different anthropogenic activities. Therefore, to minimize those activities the following recommendations should be considered.

* Local communities have not adequate awareness towards gelada baboons, awareness creation practiced should be conducted to local communities surrounding the Monastry.

* There is no clear boundary demarcation for gelada baboons around Jer Silase Monastry, so clear boundary demarcation is needed to save and conserve gelada baboons.

* Jer Silase Monastry has high potential for tourism. But, due lack of infrastructure facility like (electricity, road, transportation and lodges) there is not tourism activity. So, governments and investors should be work together to encourage and develop facilities to attract domestic and international tourists.

\section{Acknowledgement}

The author would like to thank local communities around Jer Silase Monastry their openness sharing information during data collection.

\section{References}

Afework Bekele.1996. Population dynamics of the Ethiopian endemic rodent Praomysalbipes in the Menagesha State Forest, Journal of Zoology, vol. 238 (1):1-12.

Alemneh Amare. 2015. Conservation challenges of Gibe Shelek National Park, Southwestern Ethiopia. Journal of Natural Resources, vol. 4:3.

Andren, H. 1994. Effects of habitat fragmentation on birds and mammals in landscapes with different proportions of suitable habitat: a review, Oikos, vol. 71, no. 3, pp. 355-366.

Bethan, M. 2012.The effects of logging and fragmentation on bird diversity. The Plymouth Student Scientist, 5 (2): 558-568.

Conservation International. 2011. Biodiversity hotspots.http://www.biodiversityhotspots.org/xp/Hotspots/resourc e/maps.xm Accessed date 01/04/ 2019.

Dawit Dirriba. 2012. Assessment of biomass fuel resource potential and utilization in Ethiopia: Sourcing strategies for renewable energies. International Journal of Renewable Energy Research, Vol. 2(1):131-139.

Deresse Dejene. 2003. Attitudes and Perception of Local Community towards the Ethiopian Wolf. MSc. Thesis, Durrell Institute of Conservation and Biology (DICE). University of Kent.

Donald, P. F., and Evans, A. D. 2006. Habitat connectivity and matrix restoration: the wider implications of agrienvironment schemes. Journal of Applied Ecology 43:209-218.

Engdasew Andarge. 2010. Human-wildlife conflict involving Ethiopian Wolf (Canis simensis) and gelada baboon (Theropithicus gelada) around Guassa community conservation area, North Shoa, Ethiopia [M.S. thesis], Addis Ababa University, Addis Ababa, Ethiopia.

Ethiopian Panel on Climate Change. 2015. First Assessment Report, Working Group II Biodiversity and Ecosystems, Published by the Ethiopian Academy of Sciences

Fahrig L. 2001. How much habitat is enough? Biological Conservation 100:65-74 https://scholar.google.com/citations?user=Htef610AAAAJ\&hl=en

Gippoliti, S. and Hunter, C. 2008. Theropithecus gelada. The IUCN Red List of Threatened Species 2008: e.T21744A9316114

Girma Mengesha, Yosef Mamo, Kefyalew Sahle, Chris, E. and Afework Bekele. 2014. Effects of Land-use on Birds Diversity in and around Lake Zeway. Ethiopian Journal of Science and Development 2:5-22.

Israel G. D. 1992. Determining Sample Size; Fact Sheet PEOD-6: University of Florida.

Kassahun Abie and Afework Bekele. 2016. Threats to Gelada Baboon (Theropithecus gelada) around Debre Libanos, Northwest Shewa Zone, Ethiopia, International Journal of Biodiversity, Vol. 2016: 7 pp, http://dx.doi.org/10.1155/2016/3405717.

Kassegn Berhanu and Endalkachew Teshome. 2018. Opportunities and Challenges for Wildlife Conservation: The Case of Alatish National Park, Northwest Ethiopia. African Journal of Hospitality, Tourism and Leisure, Vol. 7 (1) - (2018) ISSN: 2223-814X.

Kothari, C. 2004. Research Methodology: methods and techniques, second revised edition, New Age International (P) Ltd., publishers, New Delhi, India.

Kwaslema, M. H., Robert, D. Fyumagwa, J., Kideghesho R. and Eivin, R. 2018. Awareness and attitudes of local people toward wildlife conservation in the Rungwa Game Reserve in Central Tanzania, Human Dimensions of Wildlife, DOI:10.1080/10871209.2018.1494866

Linnen, J., Nilsen, E., Lande, U., Herfindal, I., Andersen, R. andBreitenmoses, U.,2005. Zoning as a bmeans of mitigating conflicts with largecarnivory:principles and reality.people and wildlife conflict or coexistence? Campridge, Uk, campridge university press, 162-175.

Meduna, A. J., Ogunjinmi, A. A., and Onadeko, S. A. 2009. Biodiversity conservation problems and their 
implications on ecotourism in Kainji Lake National Park,Nigeria, International Journal of Sustainable Development, vol. 10 (4) :59-73.

Melese Yihune, Afework Bekele and Zelalem Tefera. 2009. Human Gelada baboon conflict in and around the Simien Mountain National Park, African Journal of Ecology, vol. 47: 1-7.

Mengistu Wale, Abeje Kasie, Getachew Mulualem, Weldemariam Tesfahunegn, Abreham Aseffa. 2017. Wildlife threats and their relative severity of eastern Ethiopian protected area. Ecology and Evolutionary Biology, Vol. 2(4):59-67.

Pomeroy, D., Tukahirwa, J., Mugisha, S., Nanyunja, R., Namaganda, M., Chelimo, N. 2003. Linkages between Change in Land Use, Land Degradation and Biodiversity in SW Uganda.

Radeloff, V. C., Hammer, R. B., Stewart, S. I., Fried, J. S., Holocomb, S. S. and McKeefry, J. F. 2005. The wildland-urban interface in the United States. Ecological Applications Vol. 15:799-805.

Sara, E. O., Robert, W., Irene, H. and Christopher, B. D. 2014. Environmental and Anthropogenic Impacts on Avifaunal Assemblages in Urban Parkland. 4(1): 119-130.

Sefi Mekonen, Alefu Chinasho, Kassegn Berhanu and Sewnet Tesfaye. 2017. Threats and conservation challenges of wildlife in Harenna Forest, Harenna Buluk District, South East Ethiopia. International Journal of Biodiversity and Conservation, Vol. 9(7):246-255.

Solomon Chanie and Dereje Tesfaye. 2015. Threats to biodiversity conservation and ecotourism activities in Nechsar National Park, Ethiopia. International Journal of Biodiversity and Conservation, Vol. 7(2), 130-139.

Wilfred, P. 2010. Towards Sustainable Wildlife Management Areas in Tanzania. Tropical Conservation Science, 3: $103-116$. 